\title{
TRÊS POESIAS EM PORTUNHOL
}

Moema Vilela é escritora e jornalista, mestre em Semiótica pela UFMS, mestre e doutoranda em Letras pela PUCRS. E-mail: moemavilela@gmail.com

\section{la garantía}

porque soy del paraguay

preguntam-me las leys del portunhol

quiem dera las houvesse

leys en la frontera e felicidá na civilization

gabaritos para a vida, non só no vestibular

onde há anos me enganaram, colocando-me em primero

de berdá, pro que importa non hay modelo

y tampoco hay palabras qui tragam la berdá

si jo tivesse un pacto con el diablo

intergalactiko y fronteriço

lo venderia por mijones y mijones de reales

pero, de facto, num tengo

ni diablo ni diñero

\section{la rage de l'expression}

el abuelo de Douglas Diegues

viu saqueadores salindo con quatro camisas

unas por sobre las otras

cinco relógios em cada pulso

caminhones llenos de bonecas infláveis

con lo poko que habia guardado

nel forro de la loja mexicana

el abuelo de Don Wilson

cruzou la frontera rumbo a Ponta Porã

y nunca mas quis saber nada del Paraguay

la abuela de José Haroldo

carregando la madre de Joca de Sá

não podria fugir del Paraguay

só não perdonó los culpables

ensinou a su hijo o guarani 
Doze chipas em formato de ferradura, a forma retangular amassada do fogo. Tiempo cálido, cielo mayormente nublado, vientos del norte, luego al final del dia rotando al sur. Precipitaciones. No rio Ypané, homens e mulheres entram de camiseta. Latas de cerveja enterradas pela metade na areia. Esperar ( ) escurecer ( ) e mergulhar ( ) o pé na água. Torpor de chumbo em cima, ondulado latão embaixo. Brilha. Uma scooter chega. Outra scooter. Lixo só musical, uma marca de bebida, mas o resto é alívio, limpo à direita e à esquerda, são limpas as roupas coladas nos braços - só roxo, só branco, Hering no. Elas viram o celular para o próprio corpo e tiram fotos, cada uma a sua, uma do lado da outra. Os cabelos grudados no sorriso. Não sei o que fazer com a Cat Power no fone de ouvido. Falta coragem. It's a double confession. 